\title{
The Texture of Everyday Life
}

\begin{abstract}
This paper will explore some of the ways in which personal experience turns into life writing; the process in which a record of a life lived becomes a story, such as the textualization of the "texture" of life, or from body to book; the emplotment of the incidences of life into a life narrative (White); the heteroglossia of life writing (Bakhtin); the finding of voice for one's self (Eakin); and the role of memory in life writing (Olney). As a specific backdrop to the discussion, two well-known examples of Canadian literature, Susanna Moodie's Roughing It in the Bush and Margaret Atwood's reinscription The Journals of Susanna Moodie, will be used to exemplify some of the main arguments raised in the paper.
\end{abstract}

Key words

Life writing; documentariness; fictionality; memory; emplotment; metahistory; narrative self; Susanna Moodie; Margaret Atwood

Due to the general non-fictionality of its nature, which is frequently characterized as the blending of the concept of the physical author, implied author and narrator (Lejeune 1982: 193-202), life writing only conditionally belongs to literature defined in sensu stricto as fiction. By con-testing histories and stories, it exists on the margin of literature in the same way in which some persons who undertake to write a life, having found their voices in this genre, frequently live on the margin of visibility. Even though life writing has existed as a genre since ancient times, mostly in the traditional forms of autobiography, biography and memoir, it has transformed itself over the course of centuries, beginning with the first written texts of the late $18^{\text {th }}$ century (Smith and Watson 2001: 2), to become a genre in which the "other" can find his/her space of enunciation. ${ }^{1}$ But, it was only in the past thirty years or so that life writing, as a genre, would come into literary, critical and theoretical focus as one of the relevant modes of self-expression, as 
well as the object of serious study. This shift toward life writing as the dominant self-reflexive genre was mostly due to the fact that recent social and political circumstances have allowed a stronger influx of writings from the margin, or from hitherto unheard, suppressed, marginalized and silenced groups, such as indigenous peoples, ethnic minorities, blacks, women, allowing them to tell their own histories. Thus, it was around the mid-1980s in Canada that sociohistoric circumstances shifted, enabling the margin/subaltern to subvert its status of muteness or silent witness, allowing racialized, minoritized and other liminal narratives to be heard and taken into account in the general discourse of society and culture.

However, it is not only silenced and marginalized groups that have found their way of expression in life writing: an increasing number of persons want to have their voices heard, feeling they can offer their own individual experiences to the world. For some writers, life writing appears as a deeply embedded need to take note of their lives, to leave some trace of themselves behind. On the other hand, one need not necessarily relate one's own life to be a life writer: many writers narrate the lives of other persons, textually treating these lives as if they were their own. But, while the stories and perspectives in life writing differ, affecting also the choice of the written form with which life writers choose to express themselves, common to many writers is their interest in the process of creating the texture of life, in modes in which memories are shaped and poured into stories which, in turn, serve as an identity quest. This article will, therefore, focus on two of the common themes found in life writing: the first is the relevance of documentariness or factuality to life writing as a genre; and the second is the issue of factuality and memory - or, factuality versus memory - for the creation/ discovery of the self who narrates his/her life story.

In order to do this, it is necessary to tackle the issue of the factuality/fictionality of life writing. Bearing in mind that the most prominent genres of life writing are usually identified as autobiography, biography and memoir, an average reader of life-writing texts could prima facie claim that life writing is mostly non-fictional in nature and that it, therefore, belongs more to documentary genres than to literary ones. However, a closer look at life writing reveals that it, in fact, encompasses diverse literary genres, and that hence it would be more appropriate to speak of life writing as an über-genre, a trans-genre, a transgressive kind, and a collection of various narrative forms that open themselves up to writing about life, or - to use yet another denotation - a cluster of diverse genres that share the same themes. ${ }^{2}$

In written texts, there has traditionally existed a division between literature which was labelled as "fictional" and therefore "false," and history, which was seen as "factual," "documentary" and, hence, "true." Since life writing, as has just been stated, can include very different forms and modes of expression to the extent that the genres and forms it envelops bridge this often artificially imposed gap between fact and fiction, it is possible to propose a scale, a layering within the life-writing über-genre, according to the degree of literariness they possess. Literariness is, according to Roman Jakobson, that quality of writing which makes 
a given text a literary text, and which cannot be found in any other text (Jakobson qtd. in Ejxenbaum 1978: 8). ${ }^{3}$ Along those lines, and due to the play with fact and fiction within life writing, one can propose a certain refined, albeit tentative gradation on the scale of fictionality or non-fictionality within this über-genre.

Making an overall and simplified list of some of the narratives that life writing can include, at the one end of the spectrum one can encounter forms such as (auto)biographic fictions and fictionalized (auto)biographies, memoirs and histories, as well as pseudo-(auto)biographic or semi-biographic fictions and historiographic metafictions that generally depict an actual life but retain poetic freedom in depicting it; scholars more readily discuss those texts as being more literary in nature (e.g. (women's) Bildungsroman, as a classic form of auto-biographic fiction). In other words, at one end of the spectrum there are what one could call "loosely factual accounts of life," while, at the other end of this imagined scale, there are those texts that scholars discuss as being more "factual accounts of life." These are documentary accounts of individual lives that, at the same time, reflect the social and political circumstances of the lives lived and narrated: a storying life narrative or, generically somewhat different, testimonio. ${ }^{4}$ These documentary, factual (auto)biographic accounts can be verified in documents and non-fictional records of societies of which they speak; or, conversely, they fill in the gaps (lacunas) in the official histories of those societies: they bring to light the hidden histories often glossed over or misrepresented by the colonial or totalitarian past. Very often such accounts are given by living witnesses who testify to their own traumatic experiences, and are frequently ignored in official historiographies or documents; these persons are the guarantees of the truthfulness of their own accounts, which is why this genre tends to be called testimonio or witnessing: the protagonists are alive and experience is still being lived.

The question of the relevance of determining the fictionality/factuality of life writing has been the topic of literary-theoretical and critical discussions for a while now; and, in a way, it transcends the traditional classification into narratively construed (and hence fictional) texts, on the one hand, and the objective "reports based on facts" (and hence true), on the other - especially since including autobiography (the most prominent genre of life writing) within the order of non-fictional forms has been drawn into question by the realization that every text is narratively construed. The other reason for the blurring of the boundaries between the factual/fictional in life writing lies in the fact that, lately, autobiography, together with other life-writing genres, increasingly includes other literary forms such as letters, diaries or journals, and newspaper articles, which clearly belong to non-fictional literature (Adams 2000: xi). What is more, the issue of fiction/non-fiction has been additionally complicated by the "invasion" of nonverbal media such as photographs, graphs, icons, and tables into the verbal genres of life writing.

However, the fact remains that, no matter to what extent life-writing texts are "purely verbal" or are, in fact, "image-texts" (Mitchell 1994: 89, footnote 9), ${ }^{5}$ in its texture every text - be it visual (pictorial or written) or auditive (oral) - is 
a narrative. That is why the fact-or-fiction debate does not lose its significance in life writing, especially if one is aware of the ever-present Siren-song experienced by the critics and theorists to understand life-writing narratives as reliable and straight-forward Truth-statements, instead of taking them as truth-statements cum grano salis or truth-statements of an-other kind, as accounts of the possible modes of representation of a particular historical event or period from a subjective perspective, or, even more broadly, as individual representations of the experience of being "I" in particular cultures (Eakin 1999: 4). With this in mind, and in order to discuss the inherent narrativity of every text, it is necessary to take a step further away from life writing than might seem meaningful at first - a step into metahistory.

The reasoning behind such a step is as follows: If life writing does not belong, strictly speaking, to fiction, then it could be classified, judging by its subject matter involving the documentation of current historical moments, as belonging to historiography. Hayden White, the unavoidable name when speaking of historiography, in his studies of the narratological structure of historiographic texts, came to the conclusion that such texts obey the same rules as narrative (literary) texts. What White stresses is that sequences of historical events can be emplotted in various ways, depending on the historian's point of view; this imbues neutral historical events with different meanings depending on the historiographer's perspective, and also opens historical texts to different interpretations (2001: 1715). Furthermore, White stresses that historical events are turned/transformed into a story through various literary devices: by suppression or subordination of some events and by emphasizing others, by "characterization, motific repetition, variation of tone and point of view, alternative descriptive strategies, and the like - in short, all of the techniques that we would normally expect to find in the emplotment of a novel or a play" (2001: 1715; italics mine).

What is more, emplotment seems to be the strategy by which human beings process information about the outside world, the way in which the human mind works: Claude Lévi-Strauss famously stated that the mind is a structuring mechanism which imposes form on whatever material it finds at hand (2002: 9-13) by rearranging the material into bricolage or characteristic patterns of (mythological) thought (1972: 17); while Frederic Jameson claimed that narrativization is "the central function or instance of the human mind" (1981: 13; italics in the original). Linguists also agree that, ever "since the renaissance and the concomitant development of the book-industry," humans have tended "to 'literarize' all [their] experience, reduce it to a kind of 'book" (Hawkes 1977:145). In other words, many theorists speak of emplotment as a basic process through which an individual orders and transforms, and connects the frequently unconnected events and experiences from his/her life into the story of his/her life, attempting in this way to give his/her life meaning and to understand this life through the very process of (story)telling it. Consequently, the very thinking about "how our lives become stories," which is the title of a famous study on autobiography by Paul John Eakin, is a metatextual topic that life writers frequently address in the stories of (their) lives. 
It is in these emplotment strategies that both historiography and life writing agree in method. However, the key difference between them lies in the approach to the subject telling the account, the narrator: it is important to stress that a historiographic text, even though created through emplotment, negates its own narrative constructedness by representing itself as a transparent text that merely documents a historical event. Thus, the stress is on the pretence that the historical event already exists in the meaningful sequence of historical events, instead of admitting that it has post factum been embedded/woven/narrativized/textualized into the sequence by means of narrative techniques (White 1990: 21). It is by these means that the historiographic text authenticates itself, and this is where the paths of traditional historiography and life writing diverge.

When speaking of the difference between "real" historical events and imagined events in fictional discourse, White notes that "real events should not speak, should not tell themselves. Real events should simply be; they can perfectly well serve as the referents of a discourse, can be spoken about, but they should not pose as the tellers of a narrative" (1980: 8; italics in the original). And while in the monolithic, allegedly objective History with a capital " $\mathrm{H}$," the author gives credibility and authority to his text by withdrawing himself (or more precisely, by withdrawing the narrator) from the narrative, thus seemingly silencing his voice, which is nonetheless present in his very choice of literary techniques, subjectmatter and its representation. In life writing the narrator's voice - very frequently the protagonist's voice, the voice of the self telling his/her life - becomes the dominant, the governing idea of the (life)story by means of ruling, determining and transforming the other components and, thereby, ensuring the integrity of the text (Jakobson 1990: 41).

Consequently, the difference between the "objective" and "monolithic," "authoritative" and "indisputable" historiographic text by which History is written and the alternative, parallel histories that are offered by life writing lies in the subjectivity of the life writer. This voice of the "other" is precisely what characterizes life writing; the individual experience and the hitherto muted voice are required to deconstruct the grand narrative of History and create the space for little narratives (petits récits) of histories, to open up the monologue of dominant History into a dialogue of multiple histories. In other words, when the grand récit of History, along with the grand récit of Culture and Society, is deconstructed, it ceases to be monologic, and new relationships between language and the world are forged (Bakhtin 1981: 12). Furthermore, to paraphrase Mikhail Bakhtin's definition of polyglossia, this transformation raises the awareness of the interconnectedness between various voices, and creates the possibility of taking a look from different perspectives (1981: 431). ${ }^{6}$

In this multiplicity of voices, in which "everything means, is understood as a part of a greater whole - there is a constant interaction between meanings, all of which have the potential of conditioning others" (Bakhtin 1981: 426). How these voices will affect each other is determined at the moment of utterance, settled depending on the context; this is the dialogic imperative that Bakhtin speaks of, 
for it "insures there can be no actual monologue" (426). History - thus created through a multiplicity of voices and different perspectives from which the same or diverse events are related, and different life stories told - in the end creates a mosaic of dialogism, a mosaic of different voices which all together contribute to create a multifaceted history which is no longer single-voiced and monologic.

Hence, history becomes a mosaic of heteroglossia, for the context now has primacy over text: the text gains its specific meaning in the historical, social, cultural contexts in which it was created, its meaning depending on the circumstances of the moment of utterance (Bakhtin 1981: 428). In the same vein, life writing as an über-genre, with its array of subjective perspectives and voices offering a perfect image of heteroglossia at work by collecting texts dealing with an individual who notes down his/her experiences in the world, both social, political, and cultural, and how those affected his/her life and the development of his/her identity. By writing about oneself, one writes about the world, about the here and now of a particular moment in history; this is the reason why life writing not only represents the record of an individual life but also of the times.

The multiplicity of voices creating parallel histories foregrounds the importance of the individual voice which, along with its subjective perspective, now authenticates personal narrative. Thus, the perspective changes, and the self becomes the focus of life writing. Personal narrative, free of the restraints of "objective," impersonal history, chooses its own forms of expression, forms that increasingly blur the boundaries between fact and fiction. This blurring is perhaps a reflection of another question that comes to mind once life writing is defined as the story of the self (in the broadest possible sense), a question that is closely connected to the issue of factuality versus fictionality of life writing but which approaches it from another perspective: How important is actual fact in life writing? Or, in other words, what is the relationship between fact and memory for the creation or discovery of the self who narrates his/her story?

An answer to this question is certainly the notion that what shapes the self is perhaps not so much an actual event which occurred in the past, but the memory of it. The relevance of the shaping event that has remained etched in one's memory as possessing certain significance, or representing a turning or breaking point in one's life, lies in the way one's memory and imagination have re-shaped, re-created, and delivered it back to the mind. In fact, "before a perception can be registered in consciousness and thus become to us a perception, time will have passed and thrown it into memory, where other memories will affect and transform it" (Olney 1998: 339). What is more, the question arises whether it is at all possible to grasp in one's mind an unmediated perception (a "pure" perception that is not somehow already pre-shaped by the self's memories), especially if it is taken into account that an individual's very perception, as well as the interpretation of that perception, are unconsciously influenced by previous experiences or, more precisely, by the individual's memories of previous experiences (Olney 1998: 340). ${ }^{7}$

Thus, it is reasonable to claim that, when persons write about their lives, they in fact write about their memories, about their own subjective visions/versions of 
an event, and it is in this process of re-membering (piecing together anew), recreating the past that the self shapes itself. Georges Gusdorf notices, in this sense, that autobiography is "the second reading of experience, and it is truer than the first because it adds to experience itself consciousness of it" (1980: 38). ${ }^{8}$ It is how one processes the memories of events, both momentous ones as well as common, that shapes one's self. Consequently, in order to get to know one's own self, to recognize oneself as an individual, should not one try to analyze the mechanisms of how memory and imagination have wrapped themselves around events?

There is yet another question that begs to be asked: How does one know what exactly and factually happened, as opposed to the extent to which it has been re-shaped by the mind, since there are as many truths about an event as there are participants or witnesses? But, at the same time, how relevant is the knowledge of "an objective fact" when, in the end, what one remembers is the reality for one, and "[a]nything vividly imagined becomes inseparable from reality" (Penfield qtd. in Hale 2010: 62)? There is a parallelism between that which is imagined becoming reality, and that which is remembered becoming reality for an individual; hence, what makes us what we are at a particular moment in space and time is a collection of our memories of our lives, not necessarily the actual facts of our lives. What is important here to stress is that any discrepancy between the actual historical facts and one's memory of these facts does not downplay the relevance of memory.

Therefore, it is from memory that life writing texts are written. James Olney states that a life-writer who relies on memory "does so in full awareness that the temporal position he or she occupies is the present moment of the past and that an excursion into history can begin only with a backward reading from that point" (1998: 344). It is also interesting to note that memory does not only serve to look into the past. Olney claims that memory is "an adaptive function, with a self-adjusting and self-defining plasticity about it, turning back to the past so as to position itself and us for what is to be dealt with in the future" (1998: 343). He proceeds to say that it is, in fact, memory that changes according to circumstances, both "external and internal, to constitute the self as it is at any given instant" (343). This adaptability of memory serves to provide the self with a sense of stability and continuance in the face of an ever-changing environment and life's circumstances.

Hence, and as in the literary genre of the Bildungsroman, in traditional Western autobiography (often in life writing in general), the narrator is conscious that there are at least two of his/her "I-s" coexisting in the narrative: the "I" that is the protagonist of the past events, a younger "I" who has yet to learn and experience his/her life and in the process construe the identity of the older "II." This older, narratorial "I" is telling his/her life story with a retrospective gaze, as if it were happening to another person/character, and he/she therefore often takes the stance of an omniscient narrator, omniscient inasmuch as he/she has the privilege of knowing what will come after the events just narrated. Thus, the narratorial privilege consists in enjoying both a historical and a future perspective at the mo- 
ment of narration. Consequently, in traditional Western life writing there exists a paradox of sorts: the instances of the author, narrator and protagonist, which are officially conflated by life writing's claims to factuality, are, at the same time, maintained as separate by this very instance of an older narrator who looks at his/ her younger self and at life's experiences that are yet to shape him/her.

This awareness of the temporal divergence between two of the narrator's "I-s" also makes the narrator aware of the fact that, while telling his/her life story, he/ she is also construing his/her own self. ${ }^{9}$ According to Sharon Butala, the journey a writer undertakes when writing an autobiographic narrative is the journey of introspection (2010: 23); for Karl Weintraub, autobiography serves as a certain way of "self-realization" (qtd. in Anderson 2001: 4); whereas Eakin speaks of the process of "dis-covering" oneself through the process of writing (1999: x), because the "self and story are complementary, mutually constituting aspects of a single process of identity formation" (100). The narrative, in this view, becomes "identity content," and not just an "appropriate form for the expression of identity" (100). In other words, the construction of identity consists of an understanding that a narrative does not serve only to tell the story of the self, but that, on a deeper level, it represents the constitutive part of the self (101). Thus, the life story one tells of one's self is a story that one needs to tell in order to make sense of him-/her-self.

Regarding the exemplification of the constitution of the self, and the previous discussion of the role of memory and the relationship of fact/fiction in life writing, two famous literary texts of Canadian literature come to mind. These are Susanna Moodie's Roughing It in the Bush (1852) and Margaret Atwood's reinscription of them in The Journals of Susanna Moodie (1970). ${ }^{10}$ Moodie's Roughing It needs no introduction; it has been variously classified as a collection of sketches, a settler narrative and a pioneer memoir. There is no doubt that Moodie wrote the sketches with publication in mind; along with some of her poems, for a while they represented practically the only means of livelihood for the Moodie family in Canada. Consequently, the self that Susanna Moodie portrays in the sketches is a deliberately construed self, a self-conscious and self-censored revelation of a private self. This self is more or less represented from a conventional point of view, for Moodie, in the main, respected the requirements of Victorian etiquette, not only interjecting her autobiographic narrative with lyric Wordsworthian descriptions of nature, but also by refraining from explicitly writing about the hardships experienced. ${ }^{11}$ In other words, in writing her life narrative from memory, Moodie creates an appearance of keeping to the facts as they are constituted by her experiences, and re-presents them with a somewhat mediated intensity, by using a restrained style. Thus, it would seem that she offers a relatively reliable documentary account of the settlers' life in Canada, and her narrative is taken by the general critic to be one of the earliest settler accounts that paints a realistically construed picture of the times.

On the other hand, Atwood's technique consists of re-writing Moodie's (life) story in such a way as to elaborate on the feelings and sensations of Moodie's par- 
ticular memories, translating the early $19^{\text {th }}$-century experience into a $20^{\text {th }}$-century sensibility. Atwood's reinscription, re-textualization and re-contextualization in the collection of poems titled The Journals of Susanna Moodie can be classified as the genre of fictionalized auto/biography or a postmodern pseudo-journal. It is interesting to note that this pseudo-journal, to a certain extent, recalls autobiographic poetry so popular in the Romantic period in Europe, and Atwood's choice of form can be interpreted as a deliberate de(con)struction of the Romantic ideal of unity between nature and man and that Wordsworth wrote about in his poetry and theorized in his famous preface to the second edition of Lyrical Ballads (1800).

This destruction of the notion of unity between nature and woman, in fact, becomes the backbone of Atwood's Journals; Atwood uses the Moodie-persona's inability to find a common language with nature to show the fragmentation of the pioneer woman's identity upon arrival in Canada. The poems witness the sudden loss of a hitherto adequate language (of civilisation) in a new environment, and the process of a graduated re-learning of how to speak, of (re)discovering a new (natural) voice. However, in those cases in which there is an absence or abrogation of language due to the fact that the hitherto used language can no longer be relied upon to relate the new experience, there also inevitably occurs a sense of the loss of self, the loss of a continuous story about the self which would give the self a sense of identity. The outside, extra-linguistic world exists, but there is no way of knowing it because words to describe and interpret it are lacking. In this sense, Atwood portrays her Moodie-persona as an individual who undergoes the process of having to learn a new language in order to survive in these conditions, and being forced, in the meantime, to exist in the in-between world of dislocation.

This state of dislocation is, post-colonial critics agree, more or less a universal settler condition (Ashcroft et al. 2000: 73-74). However, Atwood expands it, transforming the experience of one woman into the individual experience of the modern condition: the metamorphosis of the Moodie-persona at the beginning of The Journals from "a word / in a foreign language" ("Disembarking at Quebec") to "one of the voices of the land" in the penultimate poem ("Resurrection") is well known. And, while in Roughing It Moodie retains the traditional sense of a unified self despite the extremity of her experience, Atwood takes on Moodie's original voice to expose its double marginalization and to show in its place a fragmented self that reflects a very modern inability to tell a complete (life) story, to include all of the (traumatic) experiences of one's life into one, continuous voice/ self. In this way she portrays the "dispersed and fragmented" self as "paradoxically, [...] the representative modern experience" (Hall 1996: 114; italics in the original).

There is another aspect to this fragmentedness of the self: Atwood develops and maintains the image of Moodie as a symbol of "the inescapable doubleness of her own vision" (1970: 63) and identifies this doubleness of vision in Moodie's memoir when she speaks of the inspiration for The Journals: "I suppose many of [the poems] were suggested by Mrs Moodie's books, though it was not her con- 
scious voice but the other voice running like a counterpoint through her work that made the most impression on me" (1970: 63). The simultaneous presence of the conscious and unconscious voices can be identified as the different-voicedness or heteroglossia of Roughing It, which Atwood in The Journals reinscribes in an almost psychoanalytical attempt to foreground, or at least bring to the surface the suppressed unconscious voice. This latter voice Atwood also identifies as the "othered," because obliquely present, voice within Moodie's narratorial "I" in Roughing It.

Furthermore, heteroglossia is, in The Journals, present on the narratological level as well, because the second or posterior voice, that of the "I" of Atwood's Moodie, is re-writing the first, anterior, narratorial "I" of the original Moodie. Hence, Atwood's further fictionalization or textualization/narrativization/emplotment of Moodie's self-narrative foregrounds the narrative construction of the pioneer woman's self, even in her own memoir; it, in other words, acts retroactively on the 1852 memoir to reveal the distance and artifice between the memories of the apparently lived experiences and their subsequent embodying into a book.

On the other hand, it is possible to claim that it is, in the end, not so relevant which of the "I-s" is/are factual and which fictional, as long as the story it/they narrate is relatable, identifiable, experienced empathetically and sympathetically. Through this, the process of textualization of the remembered experience becomes authenticated by the readers, offering them an-other parallel history. Bearing in mind that life writing or story(ing) life relies precisely on this transfer from body to book, i.e. on the ability of language to verbalize memory, both Moodie and Atwood, in their different ways, have achieved this. Accordingly, it is possible to propose that Atwood's Journals of Susanna Moodie represents a subtle cross-over from a women's autobiographic prose text, i.e. storying life narrative, toward a specific confessional lyric poetry that merges fact (such as it is known) and fiction, thus encompassing both ends of the life-writing spectrum, the one embedded in factuality as well as the other embedded in literariness. Moodie uses more the method of contextualization, while Atwood focuses more on textualization; the former one remembers, the latter revisits the first one's memories, taking them a step further. Consequently, Atwood is twice removed from "the real life" of Susanna Moodie and once removed ekphrastically, but in equal measure she tells one story of it, thus earning a place in the life-writing über-genre.

To conclude, the aim of this article was to offer an attempt at a generic analysis of life writing, to show the interplay of fact and fiction and the relationship between fact and memory in life writing, as well as to use two well-known literary examples to show how two texts from different ends of the life-writing spectrum function in the service of depicting an individual life, in trying to make sense of it, and in deciphering its significance not only as a documentary record of a historical period, but also as a representation of a more universal human state. 


\section{Notes}

1 The term "life writing" was coined in $18^{\text {th }}$-century England and was used interchangeably with the term "autobiography." According to Kadar, in that period life writing focused on the thematic similarities between two genres of biography and autobiography. Sometime after the $18^{\text {th }}$ century, a linguistic change took place, and the term "autobiography" gained dominant currency. It was only very recently that the concept of "life writing" appeared again, and with a greater circumference than the term "autobiography": in the $20^{\text {th }}$ century and today, "life writing" is used to as an umbrella term for any kind of personal or selfwriting, and can include certain kinds of autobiographic texts written in the $3^{\text {rd }}$ person, which is an inclusion that would never be tolerated in the genre of autobiography (2002: 660-661). Life writing covers a very wide semantic and generic field of texts depending, among other things, on the historic and cultural circumstances, subjectivities, memories, experiences, and identities of the authors. In fact, Smith and Watson list as many as 52 different genres as belonging to life writing, and they effectively include some older terms such as autobiography, apology, letters, mediation, and others (2001: 183-208). In this respect, perhaps the concept of life writing could be used not as a generic denotation, but as a definer of a mode of writing, a concept that belongs to a different kind of classification and can be combined with the "traditional" Western classification into genres. This is also the reason why Kadar, dissatisfied with the term "genre," borrows Linda Coleman's notion of the term "genus" to define life writing as "a genus for autologous writings that are structured in diverse ways" (Coleman in Kadar 1992: 20). Alternatively, Kadar also suggests the term "application" for the umbrella term "life writing" (2002: 660). It seems that the discussion between a "mode" and a "genus" and their applicability to the notion of life writing represents a certain kind of aporia in life-writing critical and theoretical circles. It would certainly be interesting to analyse the arguments in favour of each of these literary-theoretical concepts, but the space necessary for such a discussion unfortunately exceeds the limitations of this paper.

The concept of "literariness," it needs to be stressed immediately, is in this article used as an analytical tool and not an evaluative one, and is in the service of establishing a general and objective classification which may help with the analysis of life writing.

"Testimonio" is one of the most prominent terms for this kind of very documentary type of life-writing narrative, a genre that emerged most prominently in the Latin America of the late-1950s and 1960s. Like life writing, it is an umbrella term for a collection of different texts usually written in response to political upheavals against repression. The term was primarily used for such writings in Latin America, but many theorists today no longer limit its usage exclusively to that area, the term having widened its semantic and spatial scopes (Smith and Watson 2001: 206).

Sometimes similar accounts are called "storying life narratives," but some critics avoid using this term in combination with the concept "testimonio," on the grounds that the term "storying life narrative," by its choice of words, points to the storying of a lived experience, of a life turned into a story and not a testimony, which then makes the lived, witnessed experience seem somehow less "real," less factual and more storied, emplotted. There are differing opinions among the critics on this issue and on the choice of these terms.

"Image-text" is a term appropriated by W. J. Mitchell to denote an amalgam of picture and text which establishes interesting relationship between the two media, or two components of a single text. What is more, Mitchell distinguishes between the notions of "image/text," "imagetext" and "image-text" to specify the various kinds of relationships that the pictorial and verbal representations in a single text can assume (1994: 89, footnote 9). However, this concept of image/text (photography and text) appeared much earlier in Barthes. See, for example his work Image Music Text, especially pages 25-27. Barthes's Camera Lucida deals in more detail with the relationship of photography and text. 
more national languages interacting within a single cultural system" (1981: 431), but Bakhtin also uses the notion of polyglossia in the sense in which it is used in his article (1981: 12). Olney openly states that such an unmediated perception cannot exist (1998: 340). This claim is further emphasized by Smith and Watson, who claim that experience is never "simple" or unmediated, but is always mediated through memory and language; thus, it is "already an interpretation of the past and of our place in a culturally and historically specific present" (2001: 24).

8 Compare to Olney (1998: 344).

9 This division of the narratorial "I-s" into the older and younger self applies primarily to traditional Western life writing. In indigenous life writing, however, this introspection and retrospection is not necessarily present to the same extent. In fact, in indigenous life writing the distance between the narrating "I" (the older self) and the experiencing "I" (the younger self) is very small or does not exist as such because indigenous life writers usually write testimonio or witnessing about a lived experience or an experience that is still being lived. In indigenous life writing, instead of the younger/older self there can exist the distinction between the suppressed and oppressed "I," and a relatively established "I"; hence, the importance of present tense verbs in indigenous life writing.

This difference between Western and indigenous texts is another reason why the term "life writing" was introduced, for autobiography, as another term belonging to Western literary theory and practice, was inadequate and too narrow to describe indigenous and other marginal experiences. Penny Van Toorn offers a list of the main differences between traditional Western and indigenous autobiographical narratives (2000: 36-37; et passim).

10 Even though Atwood combined both of Moodie's memoirs in The Journals, only Roughing It will be analysed here in relation to The Journals.

11 However, from private letters exchanged by the members of the Strickland family in England and Canada, it appears that Moodie still transgressed the propriety norms of the English society where she initially published her work. In fact, some of her family members in England almost renounced her for disgracing all of them by revealing her intimate and private sufferings. Her ordeal is known only because she wrote to her husband about it; in her published memoirs, she consistently omitted the mention of her illnesses or private sufferings (Conway 1999). Michael Peterman's Susana Moodie: A Life (1999) is still taken to be one of the best researched biographies of Moodie's life, because it explores the "discrepancy" between her life as documented in private letters and her memoirs.

\section{References}

Adams, Timothy Dow (2000) Light Writing and Life Writing: Photography in Autobiography. Chapel Hill: University of North Carolina Press.

Anderson, Linda (2001) Autobiography. New Critical Idiom. London: Routledge.

Ashcroft, Bill, et al. (2000) Post-Colonial Studies: The Key Concepts. London: Routledge.

Atwood, Margaret (1970) The Journals of Susanna Moodie. Toronto: Oxford University Press.

Bakhtin, Mikhail (1981) The Dialogic Imagination: Four Essays by M. M. Bakhtin, Michael Holquist (ed.), Caryl Emerson and Michael Holquist (trans.). Austin: University of Texas Press. Barthes, Roland (1977) Image Music Text, Stephen Heath (ed. and trans.). London: Fontana Press. Conway, Jill Ker (1999) ‘Studying Women’s Lives'. 1 April 2011.

$<$ http://www.dce.harvard.edu/pubs/alum/1999/02.html>

Eakin, John Paul (1999) How Our Lives Become Stories: Making Selves. Ithaca: Cornell University Press.

Ejxenbaum, Boris Mikhailovich (1978) 'The Theory of the Formal Method'. In: Matejka, L., and K. Pomorska (ed.) Reading in Russian Poetics: Formalist and Structuralist Views. Michigan: Michigan Slavic Publications. 3-37. 
Gusdorf, Georges (1980) 'Conditions and Limits of Autobiography'. In: Olney, J. (ed.) Autobiography: Essays Theoretical and Critical. Princeton: Princeton University Press.

Hawkes, Terence (1977) Structuralism and Semiotics. Berkeley: University of California Press.

Hale, Amanda (2010) 'Imagining Geometry of the Soul'. In: Stephen Hardy, Martina Horáková, Michael M. Kaylor, and Kateřina Prajznerová (ed.), Transgressive (Auto)Biography as Genre and Method (Special issue of Brno Studies in English) 36(2), 61-80.

Hall, Stuart (1996) 'Minimal Selves'. In: Houston A. Baker, Jr., Manthia Diawara, and Ruth H. Lindeborg (ed.) Black British Cultural Studies. Chicago: University of Chicago Press. 114-119.

Jakobson, Roman (1990) Language in Literature. Ed. by Krystyna Pomorska and Stephen Rudy. Cambridge, MA: Belknap Press of Harvard University Press.

Jameson, Frederic (1981) The Political Unconscious: Narrative as a Socially Symbolic Act. Ithaca: Cornell University Press.

Kadar, Marlene (ed.) (1992) Essays on Life Writing: From Genre to Critical Practice. Toronto: University of Toronto Press.

Kadar, Marlene (2002) 'Life Writing'. In: New, W.H. (ed.) Encyclopedia of Literature in Canada. Toronto: University of Toronto Press. 660-666.

Lejeune, Philippe (1982) 'The Autobiographical Contract'. In: Todorov, Tzvetan (ed.) and R. Carter (trans.), French Literary Theory Today. Cambridge: Cambridge University Press. 192-222.

Lévi-Strauss, Claude (1972) The Savage Mind. London: Weidenfeld \& Nicolson.

Lévi-Strauss, Claude (2002) Myth and Meaning. London: Routledge.

Mitchell, W. J. Thomas (1994) Picture Theory: Essays on Verbal and Visual Representation. Chicago: University of Chicago Press.

Moodie, Susanna (1989) Roughing it in the Bush; or, Life in Canada. New Canadian Library. Toronto: McClelland \& Stewart.

Olney, James (1998) Memory and Narrative: The Weave of Life-Writing. Chicago: University of Chicago Press.

Peterman, Michael (1999) Susana Moodie: A Life. Toronto: ECW Press.

Smith, Sidonie, and Julia Watson (2001) Reading Autobiography: A Guide for Interpreting Life Narratives. Minneapolis: University of Minnesota Press.

Van Toorn, Penny (2000) 'Indigenous Texts and Narratives'. In: The Cambridge Companion to Australian Literature. Cambridge: Cambridge University Press. 19-49.

White, Hayden (1980) 'The Value of Narrativity in the Representation of Reality'. Critical Inquiry $7(1), 5-27$.

White, Hayden (1990) The Content of the Form: Narrative Discourse and Historical Representation. Baltimore: Johns Hopkins University Press.

White, Hayden (2001) 'The Historical Text as Literary Artifact'. In: Leitch, Vincent B. (ed.) The Norton Anthology of Theory and Criticism. New York: W. W. Norton. 1709-1729.

Vanja Polic is an assistant lecturer at the Department of English, Faculty of Humanities and Social Sciences at the University of Zagreb. She teaches Introduction to Literary Theory, English Metaphysical Poets, Modern Beginnings of the Novel in $18^{\text {th }}$-Century England, and Canadian Literature: Multiculturalism and Identity. In 2009 she defended a Ph.D. dissertation on the rhetorical practices of self-legitimation in the prefatory materials of the early $18^{\text {th }}$-century British novel. Her fields of research include identity and urban spaces in contemporary Canadian literature, and rhetorical practices of the early $18^{\text {th }}$-century British novel.

Address: Dr. Vanja Polic, Department of English, Faculty of Humanities and Social Sciences, University of Zagreb, I. Lucica 3, 10000 Zagreb, Croatia. [email: vanja.polic@zg.t-com.hr] 
